\title{
FAKTOR-FAKTOR YANG BERHUBUNGAN DENGAN PEMAKAIAN KONTRASEPSI SUNTIK 3 BULAN DI BPM KASIH BUNDA DESA SUKADAMAI KABUPATEN MUSI BANYUASIN TAHUN 2021
}

\author{
Nurul Qomariah ${ }^{1}$, Syarifah Ismed ${ }^{2}$, Titin Dewi Sartika ${ }^{3}$ \\ Prodi S1 Kebidanan, Fakultas Kebidanan dan Keperawatan,Universitas Kader Bangsa Palembang 123

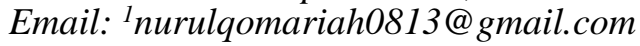

\begin{abstract}
Family Planning $(\mathrm{KB})$ is an action that helps individuals or married couples to get certain objectives, avoid unwanted births, regulate the interval between pregnancies, control the time of birth in a husband and wife relationship and determine the number of children in the family. Data from the Ministry of Health of the Republic of Indonesia in 2019, the number of family planning participants in Indonesia in 2018 was $24,196,151$ people (62.5\%) of the number of couples of childbearing age, which was 38,690,214 people. A person's decision to use contraceptives is influenced by factors of age, education, knowledge, and number of children. Income. The purpose of this study was to determine the relationship between knowledge, age, parity and income simultaneously with the use of 3-month injectable contraceptives at BPM Kasih Bunda, Sukapeace Village, Musi Banyuasin Regency in 2021.The research design uses an Analytical Survey with a Cross Sectional approach. The population in this study were all family planning acceptors who came to BPM Kasih Bunda, Sukapeace Village, Musi Banyuasin Regency, amounting to 167 people. The number of samples in this study were 63 respondents who were taken using purposive sampling technique. Data collection using a questionnaire sheet. Data analysis using univariate analysis and bivariate analysis using chi square test.The results showed that there was a relationship between knowledge ( $\mathrm{p}$ value $=0.028)$, age ( $\mathrm{p}$ value $=0.000)$, parity $(\mathrm{p}$ value $=0.023)$ and income ( $\mathrm{p}$ value $=0.004)$ with the use of 3-month injectable contraceptives at BPM Kasih Bunda, Sukapeace Village, Musi Banyuasin Regency. year 2021.The conclusion is that there is a relationship between knowledge, age, parity and income with the use of 3-month injectable contraceptives at BPM Kasih Bunda, Sukapeace Village, Musi Banyuasin Regency in 2021.
\end{abstract}

Keywords : Use of 3 Months Injectable Contraceptives, Knowledge, Age, Parity and Income

\begin{abstract}
ABSTRAK
Keluarga Berencana $(\mathrm{KB})$ merupakan tindakan yang membantu individu atau pasangan suami istri untuk mendapatkan objektif tertentu, menghindari kelahiran yang tidak diinginkan, mengantur interval diantara kehamilan, mengontrol waktu saat kelahiran dalam hubungan suami isteri dan menentukan jumlah anak dalam keluarga. Data Kementerian Kesehatan Republik Indonesia tahun 2019, jumlah peserta KB di Indonesia tahun 2018 sebanyak 24.196.151 orang $62,5 \%)$ dari jumlah Pasangan Usia Subur yaitu sebanyak 38.690.214 orang. keputusan seseorang dalam menggunakan alat kontrasepsi dipengaruhi oleh faktor umur, pendidikan, pengetahuan, jumlah anak. Pendapatan. Tujuan penelitian ini untuk mengetahui hubungan pengetahuan, umur, paritas dan pendapatan secara simultan dengan pemakaian kontrasepsi suntik 3 bulan di BPM Kasih Bunda Desa Sukadamai Kabupaten Musi Banyuasin tahun 2021. Desain penelitian menggunakan Survey Analitik dengan pendekatan Cross Sectional. Populasi pada penelitian ini adalah semua akseptor KB yang datang ke BPM Kasih Bunda Desa Sukadamai Kabupaten Musi Banyuasin yang berjumlah 167 orang. Jumlah sampel penelitian ini sebanyak 63 responden yang diambil dengan menggunakan teknik purposive sampling. Pengumpulan data menggunakan lembar kuesioner. Analisa data menggunakan analisa univariat dan analisa bivariat dengan menggunakan uji chi square. Hasil penelitian ada hubungan pengetahuan ( $p$ value $=$ $0,028)$, umur $(p$ value $=0,000)$, paritas $(p$ value $=0,023)$ dan pendapatan $(p$ value $=0,004)$ dengan pemakaian kontrasepsi suntik 3 bulan di BPM Kasih Bunda Desa Sukadamai Kabupaten Musi Banyuasin tahun 2021. Kesimpulan terdapat hubungan pengetahuan, umur, paritas dan pendapatan dengan pemakaian kontrasepsi suntik 3 bulan di BPM Kasih Bunda Desa Sukadamai Kabupaten Musi Banyuasin tahun 2021.
\end{abstract}

Kata kunci: Pemakaian Kontrasepsi Suntik 3 Bulan, Pengetahuan, Umur, Paritas dan Pendapatan 


\section{PENDAHULUAN}

Keluarga Berencana (KB) merupakan tindakan yang membantu individu atau pasangan suami istri untuk mendapatkan objektif tertentu, menghindari kelahiran yang tidak diinginkan, mengantur interval diantara kehamilan, mengontrol waktu saat kelahiran dalam hubungan suami isteri dan menentukan jumlah anak dalam keluarga. Program KB tidak hanya bertujuan untuk mengendalikan laju pertumbuhan penduduk, melainkan juga untuk memenuhi permintaan masyarakat akan pelayanan $\mathrm{KB}$ dan kesehatan reproduksi (KR) yang berkualitas, menurunkan angka kematian ibu (AKI) dan angka kematian bayi (AKB) serta penanggulangan masalah kesehatan reproduksi untuk membentuk keluarga kecil berkualitas (Yuhedi dan Kurniawati, 2017)

Kontrasepsi KB suntik ini banyak dipilih karena merupakan alternatif kontrasepsi yang sangat baik bagi wanita yang menginginkan kontrasepsi jangka panjang yang sangat efektif. Selain itu karena kontrasepsi ini juga tidak mempengaruhi proses menyusui terutama KB suntik 3 bulan, tidak bergantung pada faktor senggama, bisa digunakan oleh semua wanita usia produktif, praktis dan mudah karena mereka hanya perlu melakukannya 1 — 3 bulan sekali serta murah (Fransisca,2019).

WHO (World Health Organization) memperkirakan $76 \%$ wanita usia reproduksi yang sudah menikah atau berkeluarga memiliki kebutuhan keluarga berencana dengan metode kontrasepsi modern. Berdasarkan data WHO, menjelaskan peningkatan penggunaan kontrasepsi tertinggi adalah di Asia dan Amerika Latin, dan terendah di SubSahara Afrika. Secara global penggunaan kontrasepsi modern telah meningkat sedikit dari $49 \%$ di tahun 2014 menjadi $76 \%$ pada tahun 2016. Di Afrika dari $27 \%$ menjadi $45 \%$, di Asia telah meningkat sedikit dari 59\% menjadi $73 \%$, sedangkan di Amerika Latin dan Karibia meningkat sedikit dari $74 \%$ menjadi 80\% (WHO dalam Pratiwi, 2021).

Data Kementerian Kesehatan Republik Indonesia tahun 2019, jumlah peserta KB di Indonesia tahun 2018 sebanyak 24.196.151 orang(62,5\%) dari jumlah Pasangan Usia Subur yaitu sebanyak 38.690.214 orangdengan presentase penggunaan alat kontrasepsi suntikan $63,7 \%$. Jumlah tersebut belum memenuhi target RPJMN sebesar $66 \%$.

Berdasarkan data Dinas Kesehatan Provinsi Sumatera Selatan tahun 2020, tahun 2018jumlah peserta KB sebanyak 1.022 .746 orang $(65,4 \%)$ dari jumlah Pasangan Usia Subur yaitu sebanyak 1.563.422 orang, presentase penggunaan alat kontrasepsi suntikan 57,1\% pada tahun 2019 jumlah peserta KB mengalan peningkatan sebanyak 1.016 .855 orang $(68 \%)$ da jumlah Pasangan Usia Subur yaitu sebanyak 1.495.45 orang, dengan presentase penggunaan alat kontrasepsi suntikan 57,7\%. Jumlah tersebut mengalami peningkatan jika dibandingkan dengan (Dinkes Sumsel, 2020).
Berdasarkan data di Kabupaten Musi Banyuasin jumlah peserta KB tahun 2018 sebanyak 39.966 orang (30,7\%) dari jumlah Pasangan Usia Subur yaitu sebanyak 129.976 orang, dengan presentase penggunaan alat kontrasepsi yang paling tinggi dipilih yaitu suntikan sebesar $60,9 \%$. Kemudian mengalami peningkatan pada tahun 2019 jumlah peserta KB sebanyak 42.487 orang $(34,1 \%)$ dari jumlah Pasangan Usia Subur yaitu sebanyak 124.440 orang, dengan presentase penggunaan alat kontrasepsi yang paling tinggi dipilih yaitu suntikan sebesar 68,5\%. Target pemakaian kontrasepsi yang telah ditetapkan oleh Dinas Kesehatan Kabupaten Musi Banyuasin pada tahun 2020 sebesar $66,82 \%$ namun target hanya dapat dicapai sebanyak 34,1\%, (Dinkes Musi Banyuasin, 2020).

Data dari BPM Kasih Bunda pada tahun 2018 jumlah akseptor KB suntik sebanyak 230 orang (55\%) orang dari 418 akseptor kemudian pada tahun 2019 jumlah akseptor KB suntik mengalami peningkatan sebanyak 275 orang $(68,4 \%)$ dari 402 akseptor kemudian pada tahun 2020 jumlah akseptor KB suntik mengalami penurunan sebanyak 281 orang $(55,3 \%)$ dari 508 akseptor. Faktor penyebab turunnya akseptor menggunakan $\mathrm{KB}$ suntik dipengaruhi beberapa faktor antara lain umur akseptor yang sudah tua sehingga dianjurkan menggunakan kontrasepsi lain, pendidikan akseptor rendah, pengetahuan akseptor yang kurang tentang KB suntik dan akseptor ingin menambah anak lagi. Pada tahun 2021 dari bulan Januari - Mei jumlah akseptor KB suntik sebanyak 110 orang $(65,8 \%)$ dari 167 akseptor KB. Berdasarkan data tersebut angka penggunaan akseptor KB suntik mengalami fluktuasi setiap tahunnya. Hasil studi pendahuluan pada $10 \mathrm{ibu}$ yang menggunakan KB suntik sebanyak 8 orang memilih alasan karena KB suntik hemat biaya dan 2 orang mengatakan $\mathrm{KB}$ suntik tidak ribet.

Terkait penggunaan kontrasepsi suntik, penting untuk mengetahui faktor-faktor yang mempengaruhi pengambilan keputusan seseorang dalam memilih alat kontrasepsi. Menurut teori perilaku Andersen \& Newman dalam Notoatmodjo (2018) bahwa keputusan seseorang dalam menggunakan alat kontrasepsi dipengaruhi oleh 3 faktor yaitu faktor predisposisi (struktur sosial, kepercayaan kesehatan, dan karakteristik demografi meliputi umur, pendidikan, pengetahuan, jumlah anak), faktor pendukung (akses pelayanan kesehatan, pendapatan dan pemanfaatan asuransi kesehatan), faktor kebutuhan (persepsi terhadap status kesehatan dan simptom/ diagnosis).

Semakin tinggi tingkat pengetahuan seorang responden maka pemilihan kontrasepsi akan lebih baik, intoh pemilihan alat kontrasepsi suntik. Pengetahuan an mempengaruhi rasionalitas dalam memilih metode B. Responden lebih memilih KB suntik karena metode ini lebih murah harganya, lebih efektif, jangka waktu pemakaian lebih lama (Astuti, 2015). 
Umur seorang wanita menjadi indikator penting dalam masa reproduksinya terutama dalam upaya untuk menentukan dan mengatur kapan mereka ingin hamil dan melahirkan. Umur dalam kurun reproduksi sehat dikenal bahwa usia aman untuk kehamilan dan persalinan adalah 20 sampai 35 tahun (Wiknjosastro, 2015)

Akseptor dengan paritas rendah lebih banyak menggunakan kontrasepsi jangka pendek seperti KB suntik atau pil karena ingin memiliki anak sedangkan akseptor dengan paritas tinggi lebih memilih kontrasepsi jangka panjang berupa IUD atau implant untuk mencegah kehamilannya karena sudah memiliki cukup anak (Masita, 2016).

Penghasilan seseorang merupakan salah satu faktor yang mempengaruhi penerimaan dan pengambilan keputusan terhadap inovasi baru.Hasil penelitian menunjukan bahwa responden menggunakan kontrasepsi suntik lebih banyak yang berpendapatan Tinggi. Hal ini menunjukan bahwa keinginan Pasutri (pasangan suami istri) untuk menjadi aksepstor KB atau dalam pemilihan kontrasepsi suntik 3 bulan masih peduli dengan penggunaan kontrasepsi suntik dan ada juga sebagian aksepstor yang berpendapatan Rendah meskipun pendapatan mereka tergolong rendah karena dilihat dari segi biaya, kontrasepsi suntik yang digunakan cenderung lebih murah dibanding dengan kontrasepsi lainnya (Sriwulan, 2020).

Hasil penelitian Sriwulan (2020) dengan judul faktor yang berhubungan dengan penggunaan kontrasepsi suntik 3 bulan di Wilayah Puskesmas Tagulandang.Hasil penelitian ini menunjukan ada hubungan yang bermakna antara usia $(\rho=0,02)$, dukungan suami $(\rho=0,42)$, pendapatan $(\rho=0,01)$ dengan Penggunaan Kontrasepsi Suntik 3 bulan di Wilayah Puskesmas Tagulandang Kabupaten Sitaro.
Dari uraian di atas peneliti tertarik untuk melakukan penelitian dengan judul"Faktor-faktor yang berhubungan dengan pemakaian kontrasepsi suntik 3 bulan di BPM Kasih Bunda Desa Sukadamai Kabupaten Musi Banyuasin Tahun 2021".

Tujuan

Untuk mengetahui hubungan pengetahuan, umur, paritas dan pendapatan dengan pemakaian kontrasepsi suntik 3 bulan di BPM Kasih Bunda Desa Sukadamai Kabupaten Musi Banyuasin tahun 2021.

\section{METODE PENELITIAN}

Desain penelitian bersifat kuantitatif dengan menggunakan survey analitik dengan pendekatan crosssectional. Penelitian ini dilaksanakan di BPM Kasih Bunda Desa Sukadamai Kabupaten Musi Banyuasin pada bulan Agustus-September 2021. Populasi pada penelitian ini adalah semua akseptor KB aktif yang datang ke BPM Kasih Bunda Desa Sukadamai Kabupaten Musi Banyuasin yang berjumlah 167 orang. Besar sampel dalam penelitian ini adalah 67 responden diambil dengan menggunakan teknik purposive sampling. Instrumen penelitian berupa lembar kuesioner. Analisa data menggunakan analisa univariat dan analisa bivariat dengan uji statistik chi square

\section{HASIL PENELITIAN}

Hasil Univariat

Tabel 1 Distribusi Frekuensi Variabel Penelitian

\begin{tabular}{cccc}
\hline No. & $\begin{array}{c}\text { Pemakaian KB Suntik } \\
\text { 3 bulan }\end{array}$ & Frekuensi (f) & Persentase (\%) \\
\hline 1 & Ya & 42 & 66,7 \\
2 & Tidak & 21 & 33,3 \\
\hline & Pengetahuan & Frekuensi (f) & Persentase (\%) \\
\hline 1 & Baik & 43 & 68,3 \\
2 & Kurang & 20 & 31,7 \\
& Umur & Frekuensi (f) & Persentase (\%) \\
\hline 1 & Muda & 42 & 66,7 \\
2 & Tua & 21 & 33,3 \\
& Paritas & Frekuensi (f) & Persentase (\%) \\
\hline
\end{tabular}


Jurnal IImiah Pannmed (Pharmacyst, Analyst, Nurse, Nutrition, Midwivery, Environment, Dental Hygiene)

Vol. 16 No. 3 September - Desember 2021

\begin{tabular}{cccc}
\hline 1 & Rendah & 50 & 79,4 \\
2 & Tinggi & 13 & 20,6 \\
& Pendapatan & Frekuensi (f) & Persentase (\%) \\
\hline 1 & Tinggi & 52 & 82,5 \\
2 & Rendah & 11 & 17,5 \\
\hline & Jumlah & $\mathbf{6 3}$ & $\mathbf{1 0 0}$ \\
\hline
\end{tabular}

Hasil bivariat

Tabel 2 Hubungan variabel Independen dengan variabel Dependen

\begin{tabular}{|c|c|c|c|c|c|c|c|c|c|}
\hline \multirow{3}{*}{ No } & \multirow{3}{*}{ Variabel } & \multicolumn{4}{|c|}{ Pemakaian KB suntik 3 bulan } & & & \multirow{3}{*}{ p value } & \multirow{3}{*}{ OR } \\
\hline & & \multicolumn{2}{|c|}{$\mathbf{Y a}$} & \multicolumn{2}{|c|}{ Tidak } & \multicolumn{2}{|c|}{ Total } & & \\
\hline & & $\mathbf{n}$ & $\%$ & $\mathbf{n}$ & $\%$ & $\mathbf{n}$ & $\%$ & & \\
\hline \multirow[t]{4}{*}{$\mathbf{1}$} & Pengetahuan & & & & & & & & \\
\hline & Baik & 33 & 76,7 & 10 & 23,3 & 43 & 100 & & \\
\hline & Kurang & 9 & 45 & 11 & 55 & 20 & 100 & 0,028 & 4,033 \\
\hline & Jumlah & 42 & & 21 & & 63 & & & \\
\hline \multicolumn{10}{|c|}{2 Umur } \\
\hline & Muda & 35 & 83,3 & 7 & 16,7 & 42 & 100 & & \\
\hline & Tua & 7 & 33,3 & 14 & 66,7 & 21 & 100 & 0,000 & 10 \\
\hline & Jumlah & 42 & & 21 & & 63 & 100 & & \\
\hline \multirow[t]{4}{*}{3} & Paritas & & & & & & & 0,023 & 4,554 \\
\hline & Rendah & 37 & 74 & 13 & 26 & 50 & 100 & & \\
\hline & Tinggi & 5 & 38,5 & 8 & 61,5 & 13 & 100 & & \\
\hline & Jumlah & 42 & & 21 & & 63 & 100 & & \\
\hline \multirow[t]{4}{*}{4} & Pendapatan & & & & & & & 0,004 & 8 \\
\hline & Tinggi & 39 & 75 & 13 & 25 & 52 & 100 & & \\
\hline & Rendah & 3 & 27,3 & 8 & 72,7 & 11 & 100 & & \\
\hline & & 42 & & 21 & & 63 & 100 & & \\
\hline
\end{tabular}




\section{PEMBAHASAN}

\section{Pemakaian KB Suntik 3 Bulan}

Berdasarkan hasil penelitian didapatkan hasil bahwa dari 63 responden yang menggunakan KB suntik 3 bulan sebanyak 42 responden (66,7\%) lebih banyak dari responden yang tidak menggunakan KB suntik 3 bulan yaitu sebanyak 21 responden $(33,3 \%)$.

Hasil penelitian ini sejalan dengan hasil penelitian Astuti (2015) dengan judul faktor-faktor yang berhubungan dengan pemilihan alat kontrasepsi suntik di Klinik Pratama Sartika Bandar Lampung. Hasil penelitian menunjukkan hasil analisa univariat didapatkan sebanyak 62 orang $(82,7 \%)$ menggunakan metode kontrasepsi suntik.

Menurut Fransisca (2019), kontrasepsi KB suntik ini banyak dipilih karena merupakan alternatif kontrasepsi yang sangat baik bagi wanita yang menginginkan kontrasepsi jangka panjang yang sangat efektif. Selain itu karena kontrasepsi ini juga tidak mempengaruhi proses menyusui terutama KB suntik 3 bulan, tidak bergantung pada faktor senggama, bisa digunakan oleh semua wanita usia produktif, praktis dan mudah karena mereka hanya perlu melakukannya $1-3$ bulan sekali serta murah.

Berdasarkan hasil penelitian, penelitian terkait dan teori peneliti berasumsi bahwa KB suntik 3 bulan merupakan metode kontrasepsi yang paling diminati oleh akseptor KB. Hal ini terlihat dari tingginya penggunaan $\mathrm{KB}$ suntik 3 bulan pada akseptor KB.

\section{Hubungan Pengetahuan dengan Pemakaian KB} Suntik 3 Bulan

Berdasarkan hasil univariat diketahui bahwa dari 63 responden dengan pengetahuan baik sebanyak 43 responden $(68,3 \%)$ lebih banyak dari responden dengan pengetahuan kurang yaitu sebanyak 20 responden $(31,7 \%)$.

Hasil analisis bivariat diketahui bahwa dari 43 responden dengan pengetahuan baik ada 33 responden $(76,6 \%$ ) yang memakai KB suntik 3 bulan sedangkan dari 20 responden pengetahuan kurang ada 9 responden (45\%) yang memakai KB suntik 3 bulan.

Dari uji statistik Chi-Square pada tingkat kemaknaan $\alpha=0,05$ diperoleh nilai $p$ value $=0,028$ yang berarti ada hubungan pengetahuan dengan pemakaian kontrasepsi suntik 3 bulan, sehingga hipotesis yang menyatakan bahwa ada hubungan pengetahuan dengan pemakaian kontrasepsi suntik 3 bulan terbukti secara statistik. Hasil Odds Ratio diperoleh nilai 4,033 yang berarti bahwa responden dengan pengetahuan baik berpeluang 4,033 kali lebih besar memakai KB suntik 3 bulan dibandingkan dengan responden berpengetahuan kurang.
Hasil penelitian ini sejalan dengan teori Rizali (2013) menyatakan pengetahuan seseorang akan mempengaruhi keputusan dalam memilih metode kontrasepsi. Seseorang dengan pengetahuan yang lebih tinggi akan mempertimbangkan pemilihan alat kontrasepsi dari berbagai segi, misalnya membandingkan keuntungan dan kekurangan, kesesuaian umur dengan metode kontrasepsi suntik maupun biaya yang masih dapat dijangkau oleh responden tersebut.

Hasil penelitian ini juga sejalan dengan teori Astuti (2015) bahwa semakin tinggi tingkat pengetahuan seorang responden maka pemilihan kontrasepsi akan lebih baik, contoh pemilihan alat kontrasepsi suntik. Pengetahuan akan mempengaruhi rasionalitas dalam memilih metode KB. Responden lebih memilih KB suntik karena metode ini lebih murah harganya, lebih efektif, jangka waktu pemakaian lebih lama.

Penelitian ini sejalan dengan penelitian Yulidasari (2015) dengan judul hubungan antara pengetahuan ibu dan pekerjaan ibu dengan pemilihan kontrasepsi suntik di Kota Paringin Kalimantan Selatan. Hasil penelitian diketahui sebanyak 3 responden (6\%) memiliki pengetahuan yang kurang dan sebanyak 47 responden $(94 \%)$ memiliki pengetahuan yang baik. Hasil analisa bivariat menunjukkan ada hubungan antara pengetahuan ibu dengan pemilihan kontrasepsi suntik ( $p$ value $=0,000$ ).

Berdasarkan hasil penelitia, teori dan penelitian terkait peneliti berasumsi bahwa pengetahuan akseptor KB mempengaruhi untuk memilih kontrasepsi suntik 3 bulan, dengan pengetahuan yang baik akseptor akan dapat memahami jenis kontrasepsi, efek samping jangka waktu yang cocok dan tepat untuk digunakan.

\section{Hubungan Umur dengan Pemakaian KB Suntik 3 Bulan}

Berdasarkan hasil analisis univariat diketahui bahwa dari 63 responden dengan umur muda sebanyak 42 responden $(66,7 \%)$ lebih banyak dari responden dengan umur tua yaitu sebanyak 21 responden $(33,3 \%)$.

Hasil analisis bivariat diketahui bahwa dari 43 responden dengan pengetahuan baik ada 33 responden $(76,6 \%)$ yang memakai KB suntik 3 bulan sedangkan dari 20 responden pengetahuan kurang ada 9 responden (45\%) yang memakai KB suntik 3 bulan.

Dari uji statistik Chi-Square pada tingkat kemaknaan $\alpha=0,05$ diperoleh nilai $p$ value $=0,028$ yang berarti ada hubungan pengetahuan dengan pemakaian kontrasepsi suntik 3 bulan, sehingga hipotesis yang menyatakan bahwa ada hubungan pengetahuan dengan pemakaian kontrasepsi suntik 3 bulan terbukti secara statistik. Hasil Odds Ratio 
diperoleh nilai 4,033 yang berarti bahwa responden dengan pengetahuan baik berpeluang 4,033 kali lebih besar memakai $\mathrm{KB}$ suntik 3 bulan dibandingkan dengan responden berpengetahuan kurang.

Hasil penelitian ini sejalan dengan teori Saifuddin (2015), perencanaan keluarga menuju keluarga yang berkualitas di bagi atas tiga masa reproduksi perempuan. Pembagian ini didasarkan pada data epidemiologi, bahwa resiko kehamilan dan persalinan baik ibu maupun anak angka tertinggi pada usia kurang dari 20 tahun, terendah pada usia 20 sampai 35 tahun dan meningkat lagi secara tajam pada usia lebih dari 35 tahun. Jenis kontrasepsi yang di pakai sebaiknya juga disesuaikan dengan tahapan massa reproduksi. Kebanyakan wanita pada usia ini memilih alat kontrasepsi non MKJP seperti KB Suntik, kondom, pil atau menggunakan metode sederhana seperti metode kalender.

Hasil penelitian ini sejalan dengan teori Darmawati (2012) mengatakan kontrasepsi suntik oleh wanita usia subur (umur 20 - 35 tahun) karena suntik merupakan alat kontrasepsi yang praktis, aman, sederhana, murah dan tidak perlu takut lupa serta tidak mempengaruhi ASI. Selain itu kontrasepsi suntik memiliki efektifitas yang tinggi bila penyuntikkan dilakukan secara teratur sesuai dengan jadwal yang telah ditentukan

Penelitian ini sejalan dengan penelitian Astuti (2015) dengan judul faktor-faktor yang berhubungan dengan pemilihan alat kontrasepsi suntik di Klinik Pratama Sartika Bandar Lampung. Hasil penelitian menunjukkan hasil analisa univariat didapatkan sebanyak 62 orang $(82,7 \%)$ menggunakan metode kontrasepsi suntik, 57 orang (76\%) berumur 20-35 tahun. Hasil uji ci square diketahui ada hubungan antara umur (p-value 0,008 ) dengan penggunaan kontrasepsi suntik.

Berdasarkan hasil penelitian, teori dan penelitian terkait peneliti berasumsi bahwa salah satu faktor yang mempengaruhi akseptor memilih KB suntik 3 bulan. Pada umur 20-35 tahun merupakan umur yang baik untuk proses kehamilan dan persalinan karena pada umur tersebut organ reproduksi sudah maksimal, sehingga bila akseptor ingin menunda kehamilan dalam waktu dekat lebih banyak menggunakan KB suntik 3 bulan selain itu KB suntik 3 bulan merupakan salah satu kontrasepsi yang praktis, aman dan sederhana serta memiliki efektifitas yang tinggi.

\section{Hubungan Paritas dengan Pemakaian KB} Suntik 3 Bulan

Berdasarkan hasil analisis univariat diketahui bahwa dari 63 responden dengan paritas rendah sebanyak 50 responden $(79,4 \%)$ lebih banyak dari responden dengan paritas tinggi yaitu sebanyak 13 responden $(20,6 \%)$.
Hasil analisis bivariat diketahui bahwa dari 50 responden paritas rendah ada 37 responden $(74 \%)$ yang memakai KB suntik 3 bulan sedangkan dari 13 responden paritas tinggi ada 5 responden $(38,5 \%)$ yang memakai KB suntik 3 bulan.

Dari uji statistik Chi-Square pada tingkat kemaknaan $\alpha=0,05$ diperoleh nilai $p$ value $=0,023$ yang berarti ada hubungan paritas dengan pemakaian kontrasepsi suntik 3 bulan, sehingga hipotesis yang menyatakan bahwa ada hubungan paritas dengan pemakaian kontrasepsi suntik 3 bulan terbukti secara statistik. Hasil Odds Ratio diperoleh nilai 4,554 yang berarti bahwa responden dengan paritas rendah berpeluang 4,554 kali lebih besar memakai KB suntik 3 bulan dibandingkan dengan responden paritas tinggi.

Hasil penelitian ini sejalan dengan teori Saifuddin (2015), jumlah anak mempunyai hubungan yang bermakna dengan pemilihat alat kontrasepsi hormonal dan mempunyai hubungan keeratan sedang. Jumlah anak mulai diperhatikan setiap keluarga, semakin banyak jumlah anak maka semakin banyak pula tanggungan kepala keluarga dalam mencukupi kebutuhan material dan spiritual masing-masing anggota keluarganya. Dengan demikian pengaturan jumlah anak sudah mulai diperhatikan oleh pasangan usia subur agar tercapai kesejahteraan keluarga.

Hasil penelitian ini sejalan dengan teori Dakmawati (2020) mengatakan bahwa paritas 1 dan paritas tinggi (lebih dari 3) mempunyai angka kematian maternal yang tinggi. Risiko pada paritas 1 dapat diatasi dengan asuhan obstetrik sedangkan untuk risiko paritas tinggi dapat diatasi dengan keluarga berencana (KB). Paritas secara konsisten dikaitkan dengan niat seseorang untuk menggunakan kontrasepsi. Yang dimana dalam menggunakan kontrasepsi ini pun menunjukkan bahwa seseorang cenderung menunggu sampai memiliki jumlah anak tertentu sebelum mempertimbangkan akan penggunaan alat kontrasepsi ini sendiri. Hal ini karena banyak yang percaya bahwa dengan menggunakan kontrasepsi dapat menghambat kesuburan di masa depan.

Penelitian ini sejalan dengan penelitian Astuti (2015) dengan judul faktor-faktor yang berhubungan dengan pemilihan alat kontrasepsi suntik di Klinik Pratama Sartika Bandar Lampung. Hasil penelitian menunjukkan hasil analisa univariat didapatkan sebanyak 62 orang $(82,7 \%)$ menggunakan metode kontrasepsi suntik, 37 orang $(49,3 \%) 46$ orang $(61,3 \%)$ tergolong multipara. Hasil uji ci square diketahui ada hubungan paritas ( $\rho$-value $0,007)$ dengan penggunaan kontrasepsi suntik.

Berdasarkan hasil penelitian, teori dan penelitian terkait peneliti berasumsi bahwa paritas 
mempengaruhi akseptor untuk memilih kontrasepsi, akseptor dengan paritas rendah cenderung ingin menambah anak lagi dan lebih memilih kontrasepsi yang serasi karena banyak yang percaya bahwa dengan menggunakan kontrasepsi dapat menghambat kesuburan di masa depan. Sedangkan pada akseptor dengan paritas tinggi masih terdapat yang menggunakan $\mathrm{KB}$ suntik 3 bulan hal dikarenakan berbagai alasan seperti akseptor tidak serasi dengan kontrasepsi lain seperti AKDR dan AKBK.

\section{Hubungan Pendapatan dengan Pemakaian KB Suntik 3 Bulan \\ Berdasarkan hasil analisis univariat diketahui bahwa dari 63 responden dengan pendapatan tinggi sebanyak 52 responden $(82,5 \%)$ lebih banyak dari responden dengan pendapatan rendah yaitu sebanyak 11 responden $(17,5 \%)$.}

Hasil analisis bivariat diketahui bahwa dari 52 responden pendapatan tinggi ada 39 responden (75\%) yang memakai KB suntik 3 bulan sedangkan dari 11 responden pendapatan rendah ada 3 responden $(27,3 \%)$ yang memakai $\mathrm{KB}$ suntik 3 bulan.

Dari uji statistik Chi-Square pada tingkat kemaknaan $\alpha=0,05$ diperoleh nilai $p$ value $=0,004$ yang berarti ada hubungan pendapatan dengan pemakaian kontrasepsi suntik 3 bulan, sehingga hipotesis yang menyatakan bahwa ada hubungan pendapatan dengan pemakaian kontrasepsi suntik 3 bulan terbukti secara statistik. Hasil Odds Ratio diperoleh nilai 8 yang berarti bahwa responden dengan pendapatan tinggi berpeluang 8 kali lebih besar memakai KB suntik 3 bulan dibandingkan dengan responden pendapatan rendah.

Hasil penelitian ini sejalan dengan teori Firdaus (2018) mengatakan bahwa pendapatan keluarga adalah pendapatan yang diperoleh dari seluruh anggota yang bekerja baik dari pertanian maupun dari luar pertanian. Variasi sumbangan pendapatan dapat terjadi disebabkan oleh jumlah anggota rumah tangga yang bekerja dan sumbangan terhadap rumah tangga. Penghasilan seseorang merupakan salah satu faktor yang mempengaruhi penerimaan dan pengambilan keputusan terhadap inovasi baru. Keinginan pasutri (pasangan suami istri) untuk menjadi aksepstor $\mathrm{KB}$ atau dalam pemilihan kontrasepsi suntik masih peduli dengan penggunaan kontrasepsi suntik dilihat dari segi biaya, kontrasepsi suntik yang digunakan cenderung lebih murah dibanding dengan kontrasepsi lainnya.

Penelitian ini sejalan dengan penelitian Sriwulan (2020) dengan judul faktor-faktor yang berhubungan dengan penggunaan kontrasepsi suntik di Wilayah Puskesmas Tagulandang Kabupaten Sitaro. Hasil penelitian menunjukkan sebagian besar responden memilih penggunaan kontrasepsi suntik 3 bulan, responden memiliki usia 20-35 tahun mendapat dukungan dari suami dengan pendapatan yang baik. Dari hasil uji chi-square didapatkan hasil nilai $\rho$ untuk usia $\rho=0,02$ lebih kecil dari $\alpha=0,05$, nilai $\rho$ untuk dukungan suami $\rho=0.04$ lebih kecil dari $\alpha=0,05$, nilai $\rho$ untuk pendapatan $\rho=0,01$ lebih kecil dari $\alpha=0,05$ Yang berarti ada hubungan yang bermakna antara Usia, Dukungan suami, Pendapatan dengan Penggunaan Kontrasepsi Suntik 3 bulan di Wilayah Puskesmas Tagulandang Kabupaten Sitaro

Berdasarkan hasil penelitian, teori dan penelitian terkait peneliti berasumsi bahwa pendapatan mempengaruhi akseptor memilih kontrasepsi, banyak akseptor lebih memilih kontrasepsi suntik 3 bulan dikarenakan biayanya yang dianggap murah, penggunaannya yang tidak ribet dan aman.

\section{KESIMPULAN DAN SARAN}

\section{Kesimpulan}

1. Ada hubungan pengetahuan, umur, paritas dan pendapatan secara simultan dengan pemakaian kontrasepsi suntik 3 bulan di BPM Kasih Bunda Desa Sukadamai Kabupaten Musi Banyuasin tahun 2021.

2. Ada hubungan pengetahuan secara parsial dengan pemakaian kontrasepsi suntik 3 bulan di BPM Kasih Bunda Desa Sukadamai Kabupaten Musi Banyuasin tahun 2021 ( $p$ value $=0,028)$

3. Ada hubungan umur secara parsial dengan pemakaian kontrasepsi suntik 3 bulan di BPM Kasih Bunda Desa Sukadamai Kabupaten Musi Banyuasin tahun 2021 ( $p$ value $=0,000)$

4. Ada hubungan paritas secara parsial dengan pemakaian kontrasepsi suntik 3 bulan di BPM Kasih Bunda Desa Sukadamai Kabupaten Musi Banyuasin tahun $2021(p$ value $=0,023)$

5. Ada hubungan pendapatan secara parsial dengan pemakaian kontrasepsi suntik 3 bulan di BPM Kasih Bunda Desa Sukadamai Kabupaten Musi Banyuasin tahun $2021(p$ value $=0,004)$

\section{Saran}

1. Kepada BPM Kasih Bunda Desa Sukadamai Diharapkan dapat meningkatkan mutu pelayanan kesehatan serta pemahaman kepada masyarakat terutama pada akseptor tentang macammacam kontrasepsi sehingga dapat meningkatkan penggunaan alat kontrasepsi pada pasangan usia subur.

\section{Kepada Universitas Kader Bangsa Palembang}


Dapat menambah referensi dan pustaka serta pengetahuan bagi Mahasiswa Universitas Kader Bangsa Palembang khususnya program S1 Kebidanan.

\section{Kepada Peneliti yang akan Datang}

Sebagai bahan rujukan di dalam penelitian selanjutnya, khususnya yang mengambil permasalahan mengenai faktor-faktor yang berhubungan dengan pemakaian kontrasepsi suntik 3 bulan.

\section{DAFTAR PUSTAKA}

Amaliyah MA. (2016). Faktor-Faktor Yang Berhubungan Dengan Penggunaan KB Suntik Pada Ibu Usia Kurang Dari 20 Tahun di Puskesmas Sewon I Bantul. Jurnal Universitas 'Aisyiyah Yogyakarta. Vol 3 No 2, pp 72 - 90.

AstutiD. (2015).Faktor-faktor yang berhubungan dengan pemilihan alat kontrasepsi suntik di Klinik Pratama Sartika Bandar Lampung.Jurnal Keperawatan. Vol. XI, No. 2, pp 80-90.

BKKBN.(2015). Keluarga Berencana dan Kesehatan Reproduksi. Jakarta: BKKBN.

Budiman dan RiyantoA. (2014).Kapita Selekta Kuesioner Pengetahuan dan Sikap Dalam Penelitian Kesehatan. Jakarta: Salemba Medika.

Dakmawati IS. (2020). Hubungan sikap ibu dengan perilaku penggunaan alat kontrasepsi (KB) di Puskesmas Samarinda Kota.Jurnal Borneo Student Research. Vol 2 No 1 pp 249-255.

Darmawati.(2012). Faktor-Faktor Yang Mempengaruhi Wanita Subur Memilih Kontrasepsi Suntik. Idea Nursing Journal. Vol 2 No.3 pp 153-159

Dinkes Prov. Sumsel. (2020). Profil Kesehatan Provinsi Sumatera Selatan. Palembang: Dinkes.

Dinkes Kabupaten Musi Banyuasin. (2020). Jumlah Peserta KB Aktif di Kabupaten MUBA.Sekayu. Dinkes MUBA.

Firdaus NE.(2018). Pendapatan Keluarga dengan Pemilihan Kontrasepsi di Desa Candimulyo Jombang.Skripsi STIK Insan Cendekia Medika Jombang.

FransiscaL. (2019). Faktor-faktor yang berhubungan dengan pemilihan kontrasepsi suntik di BPM
Lismarini Palembang.Jurnal Kebidanan Al-Suaibah Palembang. Vol 9 No17 pp 48 -53

Hidayati.(2016). Metode dan Teknik Penggunaan Alat Kontrasepsi. Jakarta:Salemba Medika.

Kemenkes RI. (2019). Profil Kesehatan Indonesia.Jakarta: Kemenkes RI.

Kurniawati T. (2014). Buku Ajar Kependudukan dan Pelayanan KB. Jakarta: $\quad$ EGC.

Manuaba IBG.(2015). Ilmu Kebidanan, Penyakit Kandungan dan Keluarga Berencana untuk Pendidikan Bidan. Jakarta: EGC.

Mulyani dan Rinawati.(2013). Keluarga Berencana dan Alat Kontrasepsi. Yogyakarta :Nuha Medika

NotoatmodjoS. (2018). Promosi Kesehatan Teori dan Aplikasi. Rineka Cipta. Jakarta

Profil BPM Kasih Bunda Desa Sukadamai Kabupaten MUBA tahun 2021

Sriwulan K. (2020). Faktor-faktor yang berhubungan dengan penggunaan kontrasepsi suntik 3 bulan pada akseptor KB di wilayah Puskesmas Tagulandang. Jurnal Keperawatan Vol 8 No 1, pp 10-22

Suryani E. (2017). Penggunaan Kontrasepsi Jangka Panjang (MKJP) berdasarkan sikap suami pada Wanita Usia Subur di wilayah kerja Puskesmas Sedayu I Bantul. Yogyakarta: Universitas Alma Ata (KTI)

Walyani SE danPurwoastuti E. (2015). Panduan Materi Kesehatan Reproduksi dan Keluarga Berencana. Yogyakarta: Pustaka Baru.

WiknjosastroH. (2015). Ilmu Kebidanan.Jakarta : Yayasan Bina Pustaka Sarwono Prawirohardjo.

Yuhedi LT, Kurniawati T. (2017).Buku Ajar Kependudukan dan Pelayanan KB. Jakarta: EGC

YulidasariF. (2015). Hubungan antara pengetahuan ibu dan pekerjaan ibu dengan pemilihan kontrasepsi suntik di Kota Paringin Kalimantan Selatan.Jurnal Berkala Kesehatan. Vol 1 No 1 pp 33-36. 